\title{
KERAGAMAN BAKTERI PENAMBAT N PADA RHIZOSFIR TITONIA (Tithonia diversifolia) YANG TUMBUH PADA TANAH MASAM ULTISOL
}

\author{
Agustian ${ }^{1)}$, Rimadhani Syafei, dan Lusi Maira \\ ${ }^{1)}$ Laboratorium Biologi Tanah Fakultas Pertanian Universitas Andalas \\ Kampus Limau Manis, Padang (25163) telp. 0751-72773, Fax. 0751-777061 \\ Alamat korespondensi, email: agustian@faperta.unand.ac.id
}

\begin{abstract}
Research on biodiversity of $\mathrm{N}$-fix bacteria was performed on rhizosphere of Tithonia diversifolia grown at acid soil Ultisol. This study aimed to determine the biodiversity and populations of N-fix bacteria along with the growth rate of Tithonia and characterized the bacterial isolates obtained from the rhizosphere of this plant. Soil rhizosphere samples were taken from rhizospheres of Tithonia with different criteria of stem diameter i.e $\varnothing<3 \mathrm{~cm}$, and 3 to $6 \mathrm{~cm}$ that grown at Faculty of Agriculture Andalas University experimental station.

From these results it can be concluded that the diverse and larger population were found in Tithonia with 3 to $6 \mathrm{~cm}$ stem diameter an average of $19.7 \times 103 \mathrm{cfu}$ per $\mathrm{g}$ of soil. N-fix bacterial isolates obtained have a round, slimy, slippery and convex colonies and gram variable. Based on the color of their colonies, $\mathrm{N}$-fix bacterial isolates obtained were classified into 3 groups with the following characteristics: (1) white milk isolates (A1ps, a2ps, B3ps), flourescent white and yellow, have flagella and produce auxin, (2) yellow isolate (B2K and B3K), with yellow flourescent, have flagella and produce auxin, and (3) the clear isolates that could separated into two groups i.e the flourescent group and produce auxin and has flagella isolates (A2b, A3b, and B2b) and non flourescent group, no flagella and does not produce auxin isolates (B1b, B3B). The optimum growth conditions for the all isolates were $\mathrm{pH}$ media nearly 7 with $35^{\circ} \mathrm{C}$ incubation temperature. The translucent isolates (A3b and $\mathrm{B} 3 \mathrm{~B}$ ) have a optimum range $\mathrm{pH}$ from 4.36 to 6.17 , while isolates with a yellow colonies (B2K) has a range of incubation temperature $25^{\circ} \mathrm{C}$ to $35^{\circ} \mathrm{C}$. However, from the characterization performed could not permit to specify the isolates obtained into species.
\end{abstract}

Key words : Biodiversity, N-fix bacteria, rhizosphere, Tithonia diversifolia

\section{PENDAHULUAN}

Populasi jasad renik dalam tanah merupakan suatu komunitas yang membentuk hubungan asosiatif dengan tanaman. Salah satu contoh hubungan asosiatif ini adalah pemanfaatan eksudat akar tumbuhan tingkat tinggi oleh bakteri penambat atau penambat nitrogen $(\mathrm{N})$ yang heterotropik secara nonsimbiotik sebagai sumber energi (Barea et al, 2005; Bais et al, 2006). Keberadaan bakteri penambat $\mathrm{N}$ bebas pada daerah perakaran tanaman menguntungkan karena dapat membantu mencukupi kebutuhan $\mathrm{N}$ tanaman tersebut.

Hubungan antara bakteri penambat $\mathrm{N}$ seperti ini diduga juga terjadi pada perakaran titonia (Tithonia diversifolia). Jama et al (2000) melaporkan bahwa daun hijau titonia mengandung unsur hara yang cukup tinggi yaitu $3,5-4,0 \% \mathrm{~N} ; 0,35-0,38 \%$ fosfor $(\mathrm{P})$; 3,5 -4,1\% K ; 0,59\% kalsium (Ca) dan 0,27\% magnesium (Mg). Penelitian yang dilakukan
Hakim dan Agustian (2003, 2004) menemukan kadar hara $\mathrm{N}$ titonia yang tumbuh alami di lapangan beragam antara 2,1-3,92\% , dengan $\mathrm{C} / \mathrm{N}$ sekitar 20 dan kandungan lignin sekitar $10 \%$. Tingginya kandungan N pada Tithonia yang tumbuh pada tanah yang miskin hara menguatkan dugaan adanya bakteri nonsimbiotik pemfiksasi $\mathrm{N}$ yang berasosiasi dengan akarnya. Becking (1992) mengungkapkan bahwa Azotobacter mampu menambat setidaknya $10 \mathrm{mg} \mathrm{N}$ per gram karbohidrat yang digunakan.

Bakteri penambat $\mathrm{N}$ bersifat aerobik obligat, meskipun dapat tumbuh di bawah kandungan $\mathrm{O}_{2}$ rendah. Sebaran ekologis Azotobacter spp. sangat sulit diketahui karena berkaitan dengan beragam faktor yang menentukan. Reaksi tanah $(\mathrm{pH})$ merupakan factor penentu sebaran bakteri disamping kelembaban dan kandungan bahan organik tanah (Barnesa et al, 2007). Selain faktor kimia tanah, kondisi perakaran tumbuhan 
tingkat tinggi tempatnya hidup, juga akan mempengaruhi keragaman dan populasi bakteri penambat N (Ladha, George, dan Bohlool, 1992) dan menemukan bahwa koloni bakteri penambat $\mathrm{N}$ tidak akan berkembang baik di dalam tanah kecuali jika terjadi asosiasi dengan akar tanaman yang cocok untuknya.

Dalam tanah bakteri penambat $\mathrm{N}$ lebih banyak dijumpai pada daerah rhizosfir dari pada daerah non-rhizosfir (Franche et al, 2009). Kondisi rhizosfir yang optimal bagi pertumbuhan bakteri penambat $\mathrm{N}$ akan menyebabkan $\mathrm{N}$ yang ditambatnya semakin maksimal. Lingkungan rhizosfir yang sangat mempengaruhi kehidupan bakteri penambat $\mathrm{N}$ adalah ketersediaan senyawa karbon (C) yang dibutuhkan (Curl dan Bryan, 1985). Aktivitas mikroorganisme dalam rhizosfir dipengaruhi oleh eksudat yang ada pada rhizosfir (Bais et al, 2006), kandungan eksudat akar inilah yang merupakan salah satu faktor pertumbuhan bagi mikroorganisme (Vlastimil dan Kunc, 1988). Asam organik berupa asam sitrat yang dikeluarkan dari akar titonia (Olivarez et al, Jama, 2002) diduga juga dapat memicu pertumbuhan bakteri penambat $\mathrm{N}$ sehingga akan terjadi asosiasi antara bakteri penambat $\mathrm{N}$ dengan perakaran titonia.

Penelitian ini bertujuan untuk melihat keragaman Bakteri penambat $\mathrm{N}$, tingkat populasi serta karakteristik Bakteri penambat $\mathrm{N}$ yang didapat dari rhizosf.ir titonia yang tumbuh di Ultisol

\section{BAHAN DAN METODA}

\section{Pengambilan sampel dan analisis tanah}

Contoh tanah diambil dari rhizosfir semak titonia pada Ultisol pada kebun percobaan Fakultas PertanianUniversitas Andalas. Sampel tanah rhizosfir titonia diambil pada dua kondisi tumbuh Tithonia yaitu : rhizosfir titonia dengan lingkar batang $<3 \mathrm{~cm}$ (A) dan rhizosfir titonia dengan lingkar batang 3-6 cm (B). Tiga sampel tanah dari rhizosfir diambil menurut (Wollum, 1994) dengan cara membongkar akar. Tanah yang masih melekat pada akar dipisahkan dengan menggoyang goyang akar sehingga yang melekat pada akar hanyalah butiran-butiran kecil tanah. Sampel tanah yang diambil, disimpan dalam plastik lalu dimasukkan kedalam termos es dengan suhu $4^{\circ} \mathrm{C}$ agar aktivitas menurun dan populasi mikroorganisme pada sampel tidak berubah.
Untuk analisis kimia tanah, contoh tanah dikeringanginkan dan diayak dengan saringan $2 \mathrm{~mm}$.

Pengamatan sifat kimia tanah meliputi analisis kimia tanah sampel dari rhizosfir titonia. Analisis sifat kimia tanah ini dilakukan terhadap beberapa sifat kimia, meliputi : $\mathrm{pH}$ tanah dengan $\mathrm{pH}$ meter ; penetapan N-total tanah dengan metoda Kjeldahl ; penetapan C-organik dengan metoda Walkley and Black.

\section{Penghitungan populasi dan karakterisasi Bakteri penambat $\mathbf{N}$}

Populasi Bakteri penambat $\mathrm{N}$ ditentukan menurut metoda pengenceran menggunakan cawan agar dengan pengenceran $10^{-1}$ sampai $10^{-3}$. Sebanyak 0,2 ml suspensi tanah dari setiap pengenceran, disebarkan di setiap cawan petri yang sudah berisi media agar Sukrosa-Garam Mineral (SGM) yang tidak mengandung nitrogen. Pengamatan ciri koloni bakteri meliputi warna koloni, diameter serta bentuk permukaan koloni. Koloni Bakteri penambat $\mathrm{N}$ yang tumbuh pada media SGM terlihat berlendir atau kental. Persentase populasi Bakteri penambat $\mathrm{N}$ diperoleh dengan membandingkan populasi pada media SGM dengan populasi pada media nutrient agar (NA).

Proses karakterisasi dimulai dengan pengamatan aktivitas isolat mengenai reaksi gram dengan menggunakan $\mathrm{KOH} 3 \%$ metoda Klement, Rudolph dan Sands (1990). Pengujian kandungan flourescent pada isolat murni Bakteri penambat $\mathrm{N}$ yang telah diperoleh sebelumnya pada media Kings B lalu diinkubasi selama 24 jam pada suhu $28^{\circ} \mathrm{C}$. Pengamatan pergerakan isolat bakteri penambat $\mathrm{N}$ diamati terhadap pertumbuhan bakteri pada test tube berisi media agar SGM yang diinokulasi dengan cara penusukan lurus pada bagian tengah tabung dengan kedalaman $\pm 1,25 \mathrm{~cm}$. Kultur bakteri diinkubasikan dalam inkubator pada suhu $30^{\circ} \mathrm{C}$ selama 24 jam. Adanya pergerakan ditandai dengan medium yang berawan atau keruh sepanjang garis inokulasi akibat perpindahan bakteri.

Untuk mengetahui apakah isolat Bakteri penambat $\mathrm{N}$ yang didapatkan mampu menghasilkan IAA, digunakan metoda kolorimetrik dengan penambahan pereaksi Salkowski pada media tumbuh cair (modifikasi Bric, 1991). Perubahan warna 
media tumbuh menjadi warna merah jambu menandakan adanya IAA yang dihasilkan.

\section{Uji tumbuh isolat Bakteri penambat $\mathbf{N}$ pada beberapa kondisi media}

Proses karakterisasi dilanjutkan dengan menguji pertumbuhan isolat pada beberapa kondisi media. Masing-masing jenis isolat Bakteri penambat $\mathrm{N}$ yang telah didapat, ditumbuhkan pada berbagai kondisi media seperti $\mathrm{pH}$ mendekati $(4,5,6$, dan 7) dan temperatur $\left(25^{\circ} ; 30^{\circ}\right.$ dan $\left.35^{0}\right)$. Uji ini merupakan salah satu cara untuk mengetahui kondisi media yang cocok bagi pertumbuhan optimal isolat.

Masing-masing isolat dari biakan murni diinokulasikan pada media Sukrosa-Garam Mineral Agar yang sudah diatur pHnya (ditambahkan $\mathrm{HCl}$ untuk menurunkan $\mathrm{pH}$ dan ditambahkan $\mathrm{NaOH}$ untuk menaikkan $\mathrm{pH}$ ) serta suhu inkubasi (suhu inkubator) yang diinginkan. Pertumbuhan koloni bakteri penambat $\mathrm{N}$ pada masing-masing kondisi media diamati setiap 24 jam dan diukur dengan menggunakan kertas milimeter.

\section{HASIL DAN PEMBAHASAN}

\section{Hasil Analisis Kimia Tanah Rhizosfir Titonia}

Lahan tempat titonia dibudidayakan ini merupakan sejenis Ultisol yang tergolong tanah marginal, miskin hara dan bereaksi masam. Lahan ini pada penelitian Hakim dan Agustian (2004) diberi kapur dan tanaman yang ditanam diberi input pupuk dan dimanfaatkan untuk budidaya tanaman pangan dan hortikultura seperti jagung dan cabe dengan menggunakan titonia sebagai pagar lorong.

Kemasaman tanah contoh rhizosfir yang dianalisis menunjukkan bahwa termasuk kategori masam dengan kandungan bahan organik tergolong tinggi dengan nilai $\mathrm{C} / \mathrm{N}$ yang sangat tinggi. Hal ini menunjukkan bahwa adanya penambahan titonia sebagai sumber bahan organik ke dalam tanah melalui pengembalian pangkasan titonia dan sisa-sisa tanaman budidaya meningkatkan kandungan C-organik tanah.

Tabel 1. Hasil rata-rata dari analisis kimia tanah tiga contoh dari masing-masing rhizosfir titonia yang diteliti

\begin{tabular}{|c|c|c|c|c|}
\hline \multirow{2}{*}{$\begin{array}{c}\text { Rhizosfir } \\
\text { titonia }\end{array}$} & \multicolumn{4}{|c|}{ Sifat dan Ciri Kimia Tanah } \\
\cline { 2 - 5 } & $\mathrm{pH} \mathrm{H} \mathrm{O}$ & C-organik (\%) & N-total (\%) & Rasio C/N \\
\hline $\mathrm{A}$ & $5,47 \mathrm{~m}$ & $3,77 \mathrm{t}$ & $0,14 \mathrm{r}$ & $29,04 \mathrm{st}$ \\
$\mathrm{B}$ & $5,53 \mathrm{~m}$ & $4,11 \mathrm{t}$ & $0,14 \mathrm{r}$ & $29,26 \mathrm{st}$ \\
\hline
\end{tabular}

Keterangan : $\mathrm{m}=$ masam, $\mathrm{r}=$ rendah, $\mathrm{s}=$ sedang, $\mathrm{t}=$ tinggi $\mathrm{st}=$ sangat tinggi

A, rhizosfir dengan lingkar batang titonia $<3 \mathrm{~cm}$ dan; B, rhizosfir dengan lingkar batang titonia 3-6 cm.

\section{Populasi Bakteri penambat $\mathbf{N}$}

Pada Tabel 2 dapat dilihat bahwa ratarata populasi Bakteri penambat $\mathrm{N}$ pada rhizosfir titonia kriteria $\mathrm{B}\left(19,7 \times 10^{3} \mathrm{cfu}\right)$ lebih tinggi daripada kriteria A (15 x $\left.10^{3} \mathrm{cfu}\right)$. Ciri kimia tanah seperti $\mathrm{pH}$ yang tidak berbeda antara rhizosfir yang diteliti sepertinya tidak banyak pengaruhnya terhadap keberadaan Bakteri penambat N. Kandungan bahan organik yang berbeda walaupun berada dalam kriteria yang sama agaknya memiliki pengaruh terhadap populasi. Perbedaan tingkatan umur tanaman sesuai dengan ukuran lingkar batang yang berbeda diduga memiliki kandungan eksudat akar berbeda. Menurut Vlastimil dan Kunc (1988), Bais et al (2006) kandungan eksudat akar dapat dipengaruhi oleh jenis serta umur tanaman. Perbedaan jumlah eksudat akan menyebabkan sumber energi yang akan dimanfaatkan bakteri penambat $\mathrm{N}$ juga berbeda sehingga mempengaruhi aktivitas dan populasinya. Hal ini terlihat pada populasi bakteri penambat $\mathrm{N}$ dari rhizosfir titonia yang berukuran lingkar batang lebih besar (B) memiliki populasi lebih tinggi daripada titonia yang masih muda (A). Ditemukannya adanya cendawan mikoriza arbuskula (CMA) dan bakteri penghasil fitohormon pada rhizosfir titonia (Agustian et al, 2004, 2010 dan 2011) menguatkan dugaan terjadinya sinergis antara bakteri penambat $\mathrm{N}$ dengan kelompok mikroorganisme lainnya pada rhizosfirnya. 
Tabel 2. Hasil rata-rata populasi Bakteri penambat $\mathrm{N}$ tiga contoh dari masing-masing rhizosfir titonia yang diteliti

\begin{tabular}{|c|c|c|c|}
\hline $\begin{array}{c}\text { Rhizosfir } \\
\text { titonia }\end{array}$ & $\begin{array}{c}\text { Populasi bakteri } \\
\text { penambat N }\left(\mathrm{x} 10^{3}\right. \\
\text { upk*) }\end{array}$ & $\begin{array}{c}\text { Total Bakteri }\left(\mathrm{x} 10^{6}\right. \\
\text { upk) }\end{array}$ & $\begin{array}{c}\text { Persentase perbandingan } \\
\text { bakteri penambat N terhadap } \\
\text { total bakteri (\%) }\end{array}$ \\
\hline A & 15 & 59,3 & 0,026 \\
\hline B & 19,7 & 70,3 & 0,028 \\
\hline
\end{tabular}

Keterangan: A, rhizosfir dengan lingkar batang titonia $<3 \mathrm{~cm}$ dan B, rhizosfir dengan lingkar batang titonia 3-6 cm. *) upk = unit pembentuk koloni

Curl dan Bryan (1985) menjelaskan bahwa, tanaman yang diinokulasi dengan mikoriza dan bakteri pemfiksasi $\mathrm{N}$ memiliki populasi bakteri dan Actinomycetes yang lebih tinggi pada rhizosfirnya dibandingkan tanaman yang diinokulasi tunggal. Kerjasama antara mikoriza dan Bakteri penambat $\mathrm{N}$ akan menghasilkan suatu kondisi yang menguntungkan bagi mikroba tanah disekitarnya sehingga mempengaruhi pertumbuhan tanaman. Seberapa besar sumbangan $\mathrm{N}$ tersebut belum bisa dipastikan karena diperlukan penelitian lebih lanjut mengenai hal ini.

\section{Hasil Pengamatan Morfologis Isolat Bakteri penambat $\mathbf{N}$}

Bakteri penambat $\mathrm{N}$ yang didapat dari rhizosfir titonia, pada umumnya berbentuk bulat, berlendir, licin dan cembung. Hal serupa juga ditemukan oleh Wedastri (2002), yang menemukan isolat bakteri penambat $\mathrm{N}$ dari tanah-tanah ber-pH masam dengan karakteristik: koloni berbentuk bulat, basah (moist), halus dan cembung (convex). Hanya saja pembentukan pigmen tidak ditemukan jika kultur bakteri dibiarkan lebih dari 3 hari karena pada media tidak ditambahkan Bromthimol blue. Perbedaan berikutnya terlihat pada ukuran diameter koloni. Pada penelitian ini didapatkan ukuran diameter koloni antara 2-8 mm sedangkan Wedastri (2002) menemukan isolat bakteri penambat $\mathrm{N}$ dengan diameter 0,5-4 mm. Selain disebabkan oleh beberapa faktor yang tersebut sebelumnya, perbedaan ini juga dapat ditimbulkan oleh perbedaan media tumbuh yang digunakan serta lamanya inkubasinya.

Pada Tabel 3 dapat dilihat bahwa hasil pengamatan morfologis bakteri mengelompokkan koloni bakteri penambat $\mathrm{N}$ menjadi beberapa jenis isolat. Koloni dengan warna dan ciri yang sama dianggap sebagai isolat yang sama. Kode isolat berasal dari kriteria rhizosfir diikuti ulangan dan warna koloninya. Masing-masing isolat ini selanjutnya akan melalui proses karakterisasi.

Berdasarkan uji gram tersebut diketahui bahwa semua isolat bersifat gram variabel. isolat bakteri penambat $\mathrm{N}$ yang ditumbuhkan pada media agar Sukrosa Garam Mineral selama satu minggu ini menunjukkan reaksi gram positif. Sementara ketika dilakukan uji gram terhadap isolat murni bakteri penambat $\mathrm{N}$ yang ditumbuhkan pada media King's B dan diinkubasi tiga hari ternyata semua isolat menunjukkan reaksi gram negatif. Bakteri penambat $\mathrm{N}$ dapat bersifat gram negatif atau gram variabel. Identifikasi bakteri penambat $\mathrm{N}$ sebagai bakteri gram variabel juga pernah dibuktikan oleh Wedastri (2002) dimana isolate yang awalnya bersifat gram negatif setelah berumur dua minggu atau lebih berubah menjadi gram positif.

Hasil pengamatan aktivitas isolat lainnya yang meliputi uji kandungan flourescent, pergerakan/flagella, serta produksi auksin/IAA terlihat pada Tabel 3. Sebagian besar isolat yang diperoleh menghasilkan flourescent kecuali isolat $\mathrm{B}_{1} \mathrm{~b}$ dan $\mathrm{B}_{3} \mathrm{~b}$. Isolat $\mathrm{A}_{1} \mathrm{ps}, \quad \mathrm{A}_{2} \mathrm{ps}, \quad \mathrm{B}_{2} \mathrm{k}$ dan $\mathrm{B}_{3} \mathrm{k}$ menghasilkan flourescent berwarna kuning sedangkan isolat $\mathrm{A}_{1} \mathrm{~b}, \mathrm{~A}_{3} \mathrm{~b}, \mathrm{~B}_{2} \mathrm{~b}$ dan $\mathrm{B}_{3} \mathrm{ps}$ dengan warna koloni bening hanya berfluorescence saja.

Berdasarkan pengelompokkan Bakteri penambat $\mathrm{N}$ menurut Schlegel dan Schmidt (1994), diduga isolat yang menghasilkan flourescent kuning mendekati sifat Azotobacter vinelandii, sementara isolat dengan flourescent putih lebih mirip dengan Azotomonas agilis sedangkan isolat yang tidak menghasilkan flourescent lebih digolongkan kedalam kelompok Beijerinckia indica. Uji ini membuktikan bahwa sebagian besar isolat memiliki flagella, hanya isolat $\mathrm{B}_{1} \mathrm{~b}$ dan $\mathrm{B}_{3} \mathrm{~b}$ yang tidak memiliki. Aquilanti (2004) menjelaskan bahwa beberapa spesies bakteri penambat $\mathrm{N}$ memiliki flagella yang tersusun 
merata pada seluruh permukaan dinding sel bakteri (peritrikus). Franche et al (2009) menambahkan bahwa, Azotobacter agilis dari beberapa jenis lainnya memiliki flagella sedangkan Azotobacter chroococcum berbentuk bulat telur tanpa flagella.

Tabel 3. Hasil karakterisasi isolat Azotobakter dari rhizosfir titonia

\begin{tabular}{|c|c|c|c|c|c|c|c|}
\hline $\begin{array}{l}\text { Kode } \\
\text { isolat }\end{array}$ & $\begin{array}{l}\text { Warna } \\
\text { koloni }\end{array}$ & $\begin{array}{l}\text { Bentuk } \\
\text { koloni }\end{array}$ & $\begin{array}{l}\text { Pewarna } \\
\text { an gram }\end{array}$ & $\begin{array}{l}\text { Ukuran } \\
\text { koloni (mm) } \\
7 \text { hari } \\
\text { inkubasi } 29^{\circ} \mathrm{C}\end{array}$ & $\begin{array}{l}\text { Flourescent } \\
\text { (warna) }\end{array}$ & $\begin{array}{l}\text { Pergerakan } \\
\text { / flagella }\end{array}$ & $\begin{array}{l}\text { Produksi } \\
\text { auksin / } \\
\text { IAA }\end{array}$ \\
\hline $\mathrm{A}_{1} \mathrm{ps}$ & Putih susu & Bulat, & $-/+$ & $3-4$ & ada(kuning) & ada & ada \\
\hline $\mathrm{A}_{2} \mathrm{ps}$ & Putih susu & berlendir, & $-/+$ & $2-4$ & ada(kuning) & ada & ada \\
\hline$A_{2} b$ & Bening & licin dan & $-/+$ & $3-4$ & ada (putih) & ada & ada \\
\hline $\mathrm{A}_{3} \mathrm{~b}$ & Bening & cembung & $-/+$ & $2-5$ & ada (putih) & ada & ada \\
\hline $\mathrm{B}_{1} \mathrm{~b}$ & Bening & & $-/+$ & $2-8$ & tidak ada & tidak ada & tidak ada \\
\hline $\mathrm{B}_{2} \mathrm{k}$ & Kekuningan & & $-/+$ & $2-3$ & ada (kuning) & ada & ada \\
\hline $\mathrm{B}_{2} \mathrm{~b}$ & Bening & & $-/+$ & $2-5$ & ada (putih) & ada & ada \\
\hline $\mathrm{B}_{3} \mathrm{~b}$ & Bening & & $-/+$ & $3-4$ & tidak ada & tidak ada & tidak ada \\
\hline $\mathrm{B}_{3} \mathrm{k}$ & Kekuningan & & $-/+$ & $2-4$ & ada (kuning) & ada & ada \\
\hline $\mathrm{B}_{3} \mathrm{ps}$ & Putih susu & & $-/+$ & $2-4$ & ada (putih) & ada & ada \\
\hline
\end{tabular}

Keterangan: A (rhizosfir titonia dengan lingkar batang $<3 \mathrm{~cm}$ ), B (rhizosfir titonia dengan lingkar batang antara 3 sampai $6 \mathrm{~cm}$ ), ps = koloni berwarna putih susu, $\mathrm{b}=$ koloni tidak berwarna/bening, $\mathrm{k}=$ koloni berwarna kuning.

Melalui uji auksin ini diketahui bahwa sebagian besar isolat dapat menghasilkan auksin, terbukti dengan terbentuknya warna merah muda ketika direaksikan dengan larutan Salkowsky Ini membuktikan bahwa pada umumnya isolat Bakteri penambat $\mathrm{N}$ yang didapat dari rhizosfir titonia dapat memproduksi auksin. Azcon dan Barea (1975) menemukan adanya auksin, giberrelin dan sitokinin didalam supernatan kultur Azotobacter vinelandii dan Azotobacter beijerinckia seperti yang dihasilkan oleh Azotobacter chroococcum dan Azotobacter paspali .

Berdasarkan hasil pengamatan morfologis dan aktivitas koloni Bakteri penambat $\mathrm{N}$ tersebut dapat disimpulkan bahwa pada rhizosfir titonia terdapat tiga karakter Bakteri penambat $\mathrm{N}$ berdasarkan warna koloni yaitu : isolat dengan koloni berwarna putih susu ( $\left.A_{1} \mathrm{ps}, \mathrm{A}_{2} \mathrm{ps}, \mathrm{B}_{3} \mathrm{ps}\right)$, menghasilkan flourescent berwarna putih dan kuning, memiliki flagella dan memproduksi auksin; isolat dengan koloni berwarna kekuningan, menghasilkan flourescent berwarna kuning, memiliki flagella dan memproduksi auksin $\left(\mathrm{B}_{2} \mathrm{k}\right.$ dan $\left.\mathrm{B}_{3} \mathrm{k}\right)$; serta isolat dengan koloni tidak berwarna/bening, menghasilkan flourescent putih dan auksin serta memiliki flagella berkode $\left(\mathrm{A}_{2} \mathrm{~b}, \mathrm{~A}_{3} \mathrm{~b}\right.$, dan $\left.\mathrm{B}_{2} \mathrm{~b}\right)$ dan tidak berflourescent, tidak berflagella serta tidak memproduksi auksin ( $\mathrm{B}_{1} \mathrm{~b}$ dan $\left.\mathrm{B}_{3} \mathrm{~b}\right)$.
Hasil Uji Pertumbuhan Isolat pada

\section{Beberapa Kondisi Media}

Uji pertumbuhan lebih lanjut hanya dilakukan terhadap 5 macam isolat dengan yang berasal rhizosfir titonia Hasil pengamatan pertumbuhan koloni Bakteri penambat N pada media agar Sukrosa Garam Mineral dengan beberapa tingkat $\mathrm{pH}$ disajikan pada Tabel 4.

Semua isolat bakteri penambat $\mathrm{N}$ dapat tumbuh pada semua rentang $\mathrm{pH}$ media, akan tetapi koloni bakteri penambat $\mathrm{N}$ lebih tahan hidup pada media dengan $\mathrm{pH} 7,0$. Ini terbukti pada $\mathrm{pH}$ media 7,0 umumnya masih terjadi pertambahan diameter koloni sampai hari ke3. Dari kelima isolat yang diujikan, isolat $\mathrm{B}_{3} \mathrm{ps}$ memiliki pertambahan diameter koloni yang paling besar pada hari ke-3 inkubasi tersebut yaitu sebesar $2 \mathrm{~mm}$. Penambahan diameter koloni semakin besar sejalan dengan peningkatan $\mathrm{pH}$ media. Hal ini membuktikan bahwa isolat bakteri penambat $\mathrm{N}$ ini lebih cocok dengan $\mathrm{pH}$ mendekati 7. Isolat $\mathrm{A}_{3} \mathrm{~b}$ lebih toleran disbanding isolat lainnya terhadap $\mathrm{pH}$ masam $(\mathrm{pH}$ 4,0). Penambahan diameter koloninya sebesar $3 \mathrm{~mm}$ pada hari ke-2 lebih besar dibandingkan isolat lainnya. Isolat lainnya hanya bertambah diameter koloninya sebesar $2 \mathrm{~mm}$ dan tidak bertambah lagi pada hari ke-3. Namun demikian pada $\mathrm{pH}$ 7,0 penambahan diameter koloni terbesar dimiliki oleh isolat $\mathrm{B}_{3} \mathrm{ps}$. 
Tabel 4. Hasil pengamatan pertumbuhan koloni Bakteri penambat $\mathrm{N}$ yang ditumbuhkan pada Media Sukrosa Garam Mineral pada suhu inkubasi $28^{\circ} \mathrm{C}$ dengan beberapa tingkatan $\mathrm{pH}$ media

\begin{tabular}{lllllllllllll}
\hline & \multicolumn{10}{c}{ Diameter koloni (mm) } \\
\hline pH & $\begin{array}{c}(4,0) \\
\text { hari ke - }\end{array}$ & \multicolumn{1}{c}{$\begin{array}{c}(5,0) \\
\text { hari ke }-\end{array}$} & $\begin{array}{c}(6,0) \\
\text { hari ke - }\end{array}$ & $\begin{array}{c}\text { (7,0) } \\
\text { hari ke - }\end{array}$ \\
\cline { 2 - 10 } $\begin{array}{l}\text { Kode } \\
\text { isolat }\end{array}$ & 1 & 2 & 3 & 1 & 2 & 3 & 1 & 2 & 3 & 1 & 2 & 3 \\
\hline
\end{tabular}

Diameter koloni (mm)

\begin{tabular}{lllllllllllll}
\hline $\mathrm{A}_{2} \mathrm{ps}$ & 2 & 4 & 4 & 3 & 7 & 7 & 3 & 8 & 8 & 3 & 6,5 & 6,5 \\
$\mathrm{~A}_{3} \mathrm{~b}$ & 3 & 6 & 6 & 4 & 7 & 7 & 3 & 7 & 7 & 3 & 6,5 & 7,5 \\
$\mathrm{~B}_{3} \mathrm{ps}$ & 3 & 5 & 5 & 3 & 5 & 5 & 3 & 6 & 6 & 3 & 6,5 & 8,5 \\
$\mathrm{~B}_{3} \mathrm{~b}$ & 3 & 5 & 5 & 3 & 7 & 7 & 2 & 7 & 7 & 4 & 5 & 7 \\
$\mathrm{~B}_{2} \mathrm{k}$ & 3 & 5 & 5 & 4 & 7 & 7 & 2 & 7 & 7 & 3 & 7 & 7 \\
\hline
\end{tabular}

Jika diamati pertumbuhan isolat dengan ciri yang sama berdasarkan warna koloni pada beberapa tingkatan media, isolat dengan koloni berwarna bening $\left(A_{3} b\right.$ dan $\left.B_{3} b\right)$ memiliki pertumbuhan yang relatif paling tinggi pada hari ke-2 untuk semua rentang $\mathrm{pH}$ media agar yang dicobakan. Hal ini menunjukkan bahwa isolat Bakteri penambat $\mathrm{N}$ tersebut merupakan isolat yang toleran terhadap kemasaman media. Sementara itu, Isolat $\mathrm{A}_{2} \mathrm{ps}$ terlihat tumbuh lebih optimum pada media dengan $\mathrm{pH} 6,0$. Namun demikian, pada media dengan $\mathrm{pH} \quad 7,0$ isolat dengan koloni berwarna putih susu ( $\left.\mathrm{B}_{3} \mathrm{ps}\right)$ dianggap lebih unggul dibanding isolat lainnya. Adanya penambahan diameter koloni sampai hari ke-3 pada media dengan $\mathrm{pH}$ 7,22 membuktikan bahwa, secara umum isolat bakteri penambat $\mathrm{N}$ tumbuh optimum pada $\mathrm{pH}$ sekitar 7

Hasil uji pertumbuhan pada suhu inkubasi yang beragam (Tabel 5) menunjukkan isolat bakteri penambat $\mathrm{N}$ memiliki pertumbuhan yang lebih baik pada suhu $30^{\circ} \mathrm{C}$ dan $35^{\circ} \mathrm{C}$. Hasil ini menunjukkan isolat yang diperoleh merupakan bakteri mesofilik. Dari semua jenis isolat yang diujikan, terlihat bahwa diameter koloni isolat $\mathrm{B}_{2} \mathrm{k}$ selalu bertambah sampai hari ke-3 pada suhu inkubasi $25^{\circ} \mathrm{C}-$ $35^{\circ} \mathrm{C}$. Ini menunjukkan isolat Bakteri penambat $\mathrm{N}$ dengan kode $\mathrm{B}_{2} \mathrm{k}$ ini mampu beradaptasi dengan beberapa tingkatan suhu inkubasi $\left(25^{\circ} \mathrm{C}-35^{\circ} \mathrm{C}\right)$. Walaupun demikian suhu $35^{\circ} \mathrm{C}$ tetap merupakan suhu paling optimum bagi pertumbuhan koloni isolat $\mathrm{B}_{2} \mathrm{k}$ seperti halnya isolat lain yang diujikan.
Pada Tabel 5 terlihat bahwa isolat bakteri penambat $\mathrm{N}$ tumbuh lebih baik pada suhu $35^{\circ} \mathrm{C}$. Hal ini terbukti dengan bertambahnya diameter koloni semua isolat sampai hari ke-3 pada suhu inkubasi $35^{\circ} \mathrm{C}$. Sementara itu, pada suhu $30^{\circ} \mathrm{C}$, diameter koloni isolat $\mathrm{A}_{3} \mathrm{~b}$ dan $\mathrm{B}_{3} \mathrm{~b}$ pada hari ke-3 relatif sama (tidak terjadi penambahan diameter koloni). Hal ini menunjukkan bahwa suhu inkubasi yang optimum bagi bakteri penambat $\mathrm{N}$ pada umumnya adalah $35^{\circ} \mathrm{C}$, hanya isolat $\mathrm{A}_{2}$ ps yang dapat tumbuh optimum pada suhu inkubasi $30^{\circ}$ C.

\section{KESIMPULAN}

Dari penelitian ini terlihat bahwa tingkat pertumbuhan (umur) titonia yang ditandai dari ukuran lingkar batang berpengaruh terhadap populasi dan keragaman bakteri penambat $\mathrm{N}$. Populasi yang lebih tinggi dan beragam ditemukan pada rhizosfir titonia dengan ukuran lingkar batang $3 \mathrm{~cm}$ sampai $6 \mathrm{~cm}$. Isolat bakteri penambat $\mathrm{N}$ yang diperoleh dari rhizosfir titonia ini bersifat gram variabel dengan koloni berbentuk bulat, berlendir, licin, dan cembung yang dapat dibedakan atas 3 kelompok isolat yaitu isolat dengan warna koloni putih susu (ps), berwarna kuning (k) dan berwarna bening (b). Media mendekati $\mathrm{pH}$ 7 serta suhu sekitar $35^{\circ} \mathrm{C}$ merupakan kondisi optimal bagi pertumbuhan isolat bakteri penambat $\mathrm{N}$ dari rhizosfir titonia. Namun demikian dari karakterisasi yang dilakukan belum dapat menetapkan spesies dari isolat yang diperoleh. 
Tabel 5. Pengaruh suhu inkubasi terhadap pertumbuhan koloni bakteri penambat $\mathrm{N}$ pada Media Sukrosa Garam Mineral pada pH 7,0

\begin{tabular}{|c|c|c|c|c|c|c|c|c|c|}
\hline \multirow{2}{*}{$\begin{array}{l}\text { Suhu } \\
\text { Kode } \\
\text { isolat }\end{array}$} & \multicolumn{3}{|c|}{$\begin{array}{c}\left(25^{\circ} \mathrm{C}\right) \\
\text { hari ke- }\end{array}$} & \multicolumn{3}{|c|}{$\begin{array}{l}\left(30^{\circ} \mathrm{C}\right) \\
\text { hari ke- }\end{array}$} & \multicolumn{3}{|c|}{$\begin{array}{c}\left(35^{\circ} \mathrm{C}\right) \\
\text { hari ke- }\end{array}$} \\
\hline & 1 & 2 & 3 & 1 & 2 & 3 & 1 & 2 & 3 \\
\hline & & \multicolumn{8}{|c|}{ Diameter koloni (mm) } \\
\hline $\mathrm{A}_{2} \mathrm{ps}$ & 2 & 5 & 7 & 2 & 6 & 8 & 2 & 6 & 6 \\
\hline$A_{3} b$ & 3 & 3 & 3 & 3 & 4 & 4 & 3 & 6 & 9 \\
\hline $\mathrm{B}_{3} \mathrm{ps}$ & 3 & 5 & 5 & 3 & 6 & 7 & 3 & 6 & 9 \\
\hline $\mathrm{B}_{3} \mathrm{~b}$ & 3 & 5 & 6 & 3 & 5,5 & 5,5 & 3 & 5 & 8 \\
\hline $\mathrm{B}_{2} \mathrm{k}$ & 4 & 6 & 7 & 3 & 6,5 & 8 & 2 & 6,5 & 8,5 \\
\hline
\end{tabular}

\section{DAFTAR PUSTAKA}

Agustian. 2004. Keragaman cendawan mikoriza arbuskula (CMA) pada tithonia (Tithonia diversifolia) yang tumbuh pada berbagai ketinggian tempat di Sumatera Barat. Jurnal Stigma Vol XI No. 4. p. 85-92

Agustian, Nuriyani, L. Maira dan O. Emalinda. 2010. Rhizobakteria penghasil fitohormon IAA pada rhizosfir tumbuhan semak karamunting, titonia, dan tanaman pangan. J. Solum Vol. VII No. 1 Januari 2010: 49-60

Agustian, S. Rahmayuni dan O. Emalinda. 2011. Isolasi dan karakterisasi rhizobakteria penghasil IAA dari rhizosfir titonia (Tithonia diversifolia). Prosiding Seminar PERIPI 9 Desember 2011 di Padang. p.426447

Aquilanti, L., F. Favilli and F. Clementi. 2004. Comparison of different strategies for isolation and preliminary identification of Azotobacter from soil samples. Soil Biol. Biochem. 36: 1475-1483

Azcon, R. and J.M. Barea. 1975. Synthesis of auxins, gibberellins and cytokinins by Azotobacter vinelandii and Azotobacter beijerinckii related to effects produced on tomato plants. Plant and Soil 43: 609- 619.

Bais, H.P.,T.L. Weir, L.G. Perry, S. Gilroy and J.M. Vivanco. 2006. The role of root exudates in rhizosphere interactions with plants and other organisms. Annu. Rev. Plant Biol. 57:233-66. doi: 10.1146/ annurev.arplant.57.032905.105159
Barea, J.M., M.J. Pozo, R. ___ ón and C. Azcón-Aguilar. 2005. Microbial cooperation in the rhizosphere. J. of Exp. Botany, 56 (417), pp. 1761-1778, doi:10.1093/jxb/eri197

Barnesa, R.J., S.J. Baxtera, R.M. Lark. 2007. Spatial covariation of Azotobacter abundance and soil properties: A case study using the wavelet transform. Soil Biol. Biochem. 39 : 295-310

Becking, J.H., 1992. The family Azotobacteraceae. In: Balows, A., Trüper, G.H., Dworkin, M., Harder, W., Schleifer, K.H. (Eds.), The Prokaryotes, A Handbook on the Biology of Bacteria: Ecophysiology, Isolation, Identification, Applications. 2nd ed., vol. 4, Springer, Germany, pp. 31443170.

Brick, J.M., R.M. Bostock, S.E Silvertone. 1991. Rapid in situ assay for indoleacetic acid production by bacteria immobilized on a nitrocellulose membrane. Appl. Env. Microbiol. 57: 535-538

Curl, E dan T. Bryan. 1985. The Rhizosphere. Springer-Verlag. Berlin Heidelberg New York. Tokyo. Pp 290

Franche, C., K. Lindström and C. Elmerich. 2009. Nitrogen-fixing bacteria associated with leguminous and non-leguminous plants. Plant Soil. 321:35-59. DOI 10.1007/s11104008-9833-8

Hakim, N dan Agustian. 2003. Gulma titonia dan pemanfaatannya sebagai sumber bahan organik dan unsur hara untuk tanaman hortikultura. Laporan Penelitian Tahun I Hibah Bersaing XI/I. Proyek Peningkatan 
Penelitian Perguruan Tinggi DP3M Ditjen Dikti. Lembaga Penelitian Unand. Padang.

Hakim, N., Agustian, Oksana. E Fitra, and R Zamora. 2004. Amelioration of acid soil infertility by (Titonia diversifolia) green manure and lime application. In Proceeding $6^{\text {th }}$ International Symposium Plant-Soil Interaction at low $\mathrm{pH}$ (PSILPH) on 1-5 August 2004 in Sendai Japan. p 366-367

Jama, B. A., C. A. Palm, R. J. Buresh, A. I. Niang, C. Gachengo, G. Nziguheba, B. Amadalo. 2000. Tithonia diversifolia as a Green Manure for Soil Fertility Improvement in Western Kenya: a Review Agroforestry System. p. 201-221

Klement, Z., K. Rudolph dan D. C. Sand. 1990. Methods in Phytobacteriology. Budapest. Academic Kiado. 57 p

Ladha, J. K. , T. George dan B.B. Bohlool. 1992. Biological Nitrogen Fixation for Sustainable Agriculture. London. Kluwer Academic (Publishers). $\quad$ pp. 209
Olivares, E., E. Peña, G. Aguiar. 2002. Metals and oxalate in Tithonia diversifolia (Asteraceae): concentrations in plants growing in contrasting soils, and $\mathrm{Al}$ induction of oxalate exudation by roots. J. of Plant Physiol., 159 (7), p. 743-749

Vlastimil, V dan F. Kunc. 1988. Soil Microbial Associations. Prague. Institut of Microbiology of the Czechoslovakia Academy of Sciences. Czechoslovakia. p 84-130

Wedastri, S. 2002. Isolasi dan Seleksi Azotobacter spp. Penghasil Faktor Tumbuh dan Penambat Nitrogen dari Tanah Masam. J. Ilmu Tanah dan lingkungan 3:45-51

Wollum, A.G. 1994. Soil sampling for microbiological analysis in Methods of Soil Analysis Part 2 Microbiological and Biochemical Properties ed R.W. Weaver et.al. Soil Sci. Soc. Am. Inc 